\title{
IAMJ
}

INTERNATIONAL

AYURVEDIC

MEDICAL JOURNAL

\section{AYURVEDA UNDERSTANDING OF KATISHULA (LOW BACK PAIN) AS A VYADHI OR LAKSHANA: A HISTORICAL REVIEW}

\author{
Rashmi.B.M. ${ }^{* 1}$ \\ Assistant Professor, Department of Roga Nidana \& Vikruti Vignyana, Government Ayurvedic Medical College \\ and Hospital, Bengaluru-09., Karnataka, India
}

Corresponding Author: drrashmibm@gmail.com

https://doi.org/10.46607/iamj3509042021

(Published Online: April 2021)

Open Access

(C) International Ayurvedic Medical Journal, India 2021

Article Received:18/03/2021 - Peer Reviewed:26/03/2021 - Accepted for Publication:27/03/2021

Check for updates

\section{ABSTRACT}

Low back pain is a very common health problem worldwide and a major cause of disability affecting performance at work and general well-being. Though several risk factors have been identified including occupational posture, depressive moods, obesity, body height and age, the causes of the onset of low back pain remain obscure and diagnosis difficult to make. Low back pain affects people of all ages, from children to the elderly, and is a very frequent reason for medical consultations. The 2010 Global Burden of Disease Study estimated that low back pain is among the top 10 diseases. Prevalence increases and peaks between the ages of 35 years and 55 years. Katishula or Low back pain is one of the Vataja Nanatmaja vikaras. The symptoms of Katishula explained in the Classics when compared to Low back pain almost appear similar, so we can co-relate Katishula with Low back pain. Many a times in our clinical practice we come across patients complaining of Katishula (low back pain) as a common symptom which can be seen in many of the diseases with different way of presentation based on the severity of the condition. Hence the Present article is built on a detailed historical search on Katishula as per the various classical references, in understanding it merely as a symptom or the disease proper.

Keywords: Low back pain, Katishula, Vataja nanatmaja vikara. 


\section{INTRODUCTION}

Low back pain is a common disorder involving the muscles, nerves and bones of the back. Pain can vary from a dull constant ache to a sudden sharp feeling. Low back pain can be classified by duration as acute (Pain lasting less than 6 weeks), sub-chronic (6 to 12 weeks), or chronic (more than 12 weeks), The condition may be further classified by the underlying cause as either mechanical, non-mechanical or referred pain. Synonyms for Low back pain: Lower back pain, Lumbago.

Usual Onset: 20 to 40 years of age,

Duration: $\sim 65 \%$ get better in 6 weeks,

Causes: Usually non-specific, occasionally significant underlying cause.

Diagnostic Method: Medical imaging (if red flags). In most episodes of low back pain, a specific underlying cause is not identified or even looked for, with the pain believed to be due to mechanical problems such as muscle or joint strain. If the pain does not go away with conservative treatment or if it is accompanied by "red flags" such as unexplained weight loss, fever, or significant problems with feeling or movement, further testing may be needed to look for a serious underlying problem. In most cases, imaging tools such as $\mathrm{X}$-ray, computed tomography are not useful and carry their own risks. Despite this the use of imaging in low back pain has increased. Some low back pain is caused by damaged intervertebral discs, and the straight leg raise test is useful to identify this cause. Initial management with non-medication-based treatments is recommended. NSAIDs are recommended if these are not sufficiently effective. A number of other options are available for those who do not improve with usual treatment. Opioids may be useful if simple pain medications are not enough, but they are not generally recommended due to side effects. Surgery may be beneficial for those with disc related chronic pain and disability or spinal stenosis. About $40 \%$ of people have LBP at some point in their lives, with estimates as high as $80 \%$ among people in the developed world. Men and women are equally affected. ${ }^{1}$

\section{Historical Review of Katishula (Low Back Pain):}

History of any science is a cluster of facts and it helps to provide the guidelines about the present and future of concerned subject. Knowledge of History is foremost step in the research field, as beside the basic ideas, it also provides the premier guidelines for further research. A Critical review of the history from the primitive stage to the present time assists to understand the future in a better way. Hence an attempt is being made to review the historical background of Katishula.

Vedic Period: It includes Veda and few other classics. But there is no mentioning of disease Katishula as such in Veda.

\section{Samhita Kala:}

This is the period when Ayurvedic system of medicine was methodically arranged in a rational way with scientific terminology. "Katishula" being most common disease in clinical practice is not explained in any of the Bruhatrayis. But it is explained as a lakshana in ajeerna, kshata-ksheena and. Vataja Jwara.In SuShrutha Samhita although Katishula is not enlisted in Nanatmaja Vata Vyadhi or as a separate disease but the references of Katishula are found in various contexts. Like in differential diagnosis of Antah Vidradhi, Katishula explained as a symptom in Vrukka Vidradhi ${ }^{2}$. While explaining the conditions due to overeating, Katishula also given. It is also given as the symptom in Urahkshata and Ajeerna condition. In the indication of Baladi Niruha Basti, Katishula is also enlisted. In Astanga Hridaya Katishula is explained as a symptom in Vataja Jvara. Bhela has classified Vata Vyadhi into two groups, Sarvanga Roga and Ekanga Roga. Katishula can be considered under Ekanga Ro$\mathrm{ga}^{3}$.In Sharangadhara Samhita, Katishula has been considered as a Vata Nanatmaja Vikara. ${ }^{4}$

In Gada Nigraha, Katishula is dealt as a separate disease in Vata Vyadhi and various formulations have been explained for its treatment ${ }^{5}$.

Madhyama Kala: Bhava Prakasha explains Katishula as a separate disease in Amavata Chikitsa Adhikara and has specified some Shamana Yoga for treating it $^{6}$.In Yogaratnakara various references of Katishula 
are available in the context of Vataja Arshas, GudasthitaVata and PakwashayagataVata Lakshana ${ }^{7}$. In Brihat Nighantu Ratnakara and Dhanwantari Nighantu Katishoola is explained in the context of Bhagandara $^{8}$.

Adhunika Kala: Bhaishajya Ratnavali which is composed during this period, chiefly contains the treatment aspects and in particular the use of Guggulu Kalpana in Katishula 9 . In Nidana ChikitsaHastamaalaka, Prathama khanda of author Dr. Ranjith Rai Desai, quoted an example for Katishula with respect to Upashayatmaka adhyayana i.e. with Murchita tila taila (snigdoshna) and Shunthi choorna (Rukshoshna) to access the guna of vata which is involved in the actual pathology of Katishula. As both ruksha guna and sheetha guna can aggravate vata to produce Katishula. ${ }^{10}$

Thus by seeing the above mentioned scattered references of Katishula in various textbooks (oldest to the latest one), it can be understood that Katishula can be taken as a main disease or merely a lakshana (symptom) itself in various diseases based on the severity and its way of presentation.

Many of the classical texts have explained Katishula as a symptom seen in various diseases.ex.in vataja arshas, gudasthita vata, pakwashayagatavata, Bhagandara, vatajajwara.

In our day today practice we come across obese patients complaining of Katishula (low back pain) due to sedentary lifestyle habits, wrong postures and so on. Such patients initially complain of low back pain which may turn to disease sciatica in later stages wherein patient complains of low back pain, associated with pain radiating to lower limbs- unilateral or bilateral.

Even most of the females post-LSCS (Lower Segment Caesarean Section) complains of low backpain (Katishula) as a complication due to spinal anaesthesia. So one has to rule out the possible cause for the Katishula or Low back pain as it is rightly said Nidanaparivarjanameva chikitsa i.e. based on the exact causative factor responsible for the disease or symptom itself one has to plan Vyadhi-pratyaneeka chikitsa or Lakshanika-chikitsa accordingly. Katishula (Low back- pain) can be seen due to heavy weight lifting which may eventually lead to IVDP (Inter-vertebral disc prolapse) and here the possible conventional treatment is either the traction or one has to go for the surgical intervention to correct the disc prolapse. Understanding the specific cause will pave the way for proper diagnosis of the disease as well to cure the disease or symptom successfully at the right time and avoiding further any complications related to the condition. Thus, Katishula can be a lakshana or a vyadhi itself based on the severity and way of presentation. One has to diagnose it thoroughly by interrogating the patient regarding proper and specific causative factors and subjecting the patient to general, physical and systemic examination, conducting various tests followed by proper diagnosis and treat accordingly will yield a much better result.

\section{CONCLUSION}

Katishula is one among Vataja-nanatmaja vyadhi's caused due to vitiated vata. ${ }^{11}$ If we have a keen focus on the classical texts, we hardly find explanation regarding the disease Katishula and its lakshanas. Acharyas have used various synonyms for the disease Katishula and highlighted more on its treatment aspects rather than its symptoms, as the name itself defines it as pain in the Kati pradesha.

\section{REFERENCES}

1. https://en.m.wikipedia.org/wiki/Low_back_pain on $17 / 03 / 2021$ at $12.50 \mathrm{pm}$.

2. Sushruta; Sushruta samhita with Nibandha sangraha and Nyaya chandrika teeka; Chaukamba orientalia, Varanasi; English edition (2005); Chikitsasthana: 32:21; Dalhana commentary.

3. Krishna Murthy KH. (ed), Bhela Samhitha, English translation, Sharma.P.V., Chikitsa sthana, Chapter-24, Diseases due to vata, Varanasi: Choukambha Vishvabharathi; 2008.p.448.

4. Shrikanta Murthy KR, Sharangadhara Samhitha, Sharangadhara, English translation, Prathama khanda, Chapter -7, Rogaganana Adhyaya, $4^{\text {th }} \mathrm{ed}$, Varanasi: Choukambha Orientalia; 2001. p.31.

5. Tripaty I, GadaNigraha, Vaidhya Shodala, Hindi commentary, Vidhyotini, Hindi Translation, Vol-2, 
Vatavyadhi Nidana, Varanasi: Choukambha Samskrita Samsthana; 2011.p. 486

6. Shrikanta Murthy KR, Bhava Prakasha, Bhavamishra, Hindi commentary, Vidhyotini, Vol-2, Madhyama Khanda, chapter-24, Vatavyadhi Adhikara, Varanasi: Krishna Das Academy; 2002. p.329.

7. Asha Kumari, P.V. Tiwari, Yogaratnakara, Part-2, Choukambha Vishwaharati, Varanasi; First edition;2010. p.727,729,752.

8. Dr. S. D. Kamat, Dhanvantari-Nighantu, Choukambha Sanskrit Pratishthana, Delhi; First published-2002; p.352.

9. Siddinandana Mishra, Bhaishajya Ratnavali, Kaviraja Shri Govinda Dasa Sena, Siddhiprada Hindi Vyakhya, Vata Vyadhi Adhikara, Chouksmbha Publishing House, New Delhi; p.522-23.

10. Desai RR, Nidana Chikitsa Hastamalaka, Prathama khanda, Chapter- 10, Pancha Nidana, New ed.Kolkatta: Shri Vaidhyanaatha Ayurveda Bhavana; 2000.p.60102 .

11. Shrikanta Murthy KR, Sharangadhara Samhitha, Sharangadhara, English translation, Prathama khanda, Chapter -7 , Rogaganana Adhyaya, $4^{\text {the }}$, Varanasi: Choukambha Orientalia; 2001. p.31.

\section{Source of Support: Nil \\ Conflict of Interest: None Declared}

How to cite this URL: Rashmi. B. M: Ayurveda Understanding of Katishula (Low Back Pain) As A Vyadhi Or Lakshana: A Historical Review. International Ayurvedic Medical Journal \{online\} 2021 \{cited April, 2021\} Available from:

http://www.iamj.in/posts/images/upload/896 899.pdf 